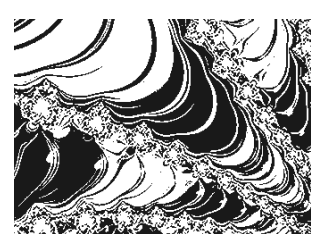

https://doi.org/10.5559/di.29.1.04

\title{
COMBINING INDIVIDUAL AND COLLECTIVE EMPLOYEE INCENTIVES TO ENHANCE ORGANIZATIONAL PERFORMANCE
}

Maja KLINDŽIĆ, Lovorka GALETIĆ

Faculty of Economics and Business, Zagreb

UDK: $331.108 .5(497.5)$

$005.66(497.5)$

Izvorni znanstveni rad

Primljeno: 23. 10. 2018.

This research paper has been supported by the Croatian Science Foundation's funding of the project HRZZ-IP-2014-09-

A large body of literature provides empirical evidence of a positive relationship between reward practices and performance. However, little has been said about different combinations of individual and group incentives as drivers of organizational competitiveness. This paper examines bundles of nine individual and group PFP practices and their joint effect on selected financial and non-financial indicators of organizational performance (OP). Our empirical research study included 61 middleand large-sized companies in Croatia in order to analyze the aforementioned relationships. The categorical principal component analysis generated two factors of PFP practices that were subsequently used as independent variables in a multiple regression analysis. The first PFP bundle consisted of individual subjectively-based bonus and two shared-ownership practices and was found to positively influence non-financial indicators of $O P$, i.e. quality of services or products and innovativeness. The second factor consisted of individual performance appraisal and profit-sharing and it positively influenced financial indicators of $\mathrm{OP}$, i.e. productivity and, to a lesser extent, profitability. Implications for theory and practice are also discussed.

Keywords: compensation management, pay for performance (PFP), individual bonus, group bonus, bundles of PFP practices, organizational performance

Maja Klindžić, University of Zagreb, Faculty of Economics and Business, Department of Organization and Management, Trg J. F. Kennedyja 6, 10000 Zagreb, Croatia. E-mail: mklindzic@net.efzg.hr 
In today's challenging business environment, the need to use pay strategically is more important than ever as organizations and their leaders look for ways to improve outcomes, performance, productivity, and teamwork (Gross \& Friedman, 2004; Perkins, White, \& Jones, 2016). In doing so, linking rewards to business goals and competencies is essential to gaining competitive advantage through people (e.g. Chen \& Wang, 2018; Milkovich, Newman, \& Gerhart, 2016). Reinforcement theory identifies monetary rewards as one of the most important channels through which organizations can reinforce behaviors (Skinner, 2014 after Gallani, 2017); however, not all monetary rewards are equal (Kato \& Kauhanen, 2018).

Monetary rewards are usually thought of as a sum of base pay, variable incentives and benefits, i.e. all financial rewards that an employee can obtain for work performed (Milkovich et al., 2016). While direct monetary compensation in the form of base pay is a steady source of income providing security for employees (e.g. Galetić, 2015), indirect compensation or benefits are more likely to affect the sense of belonging to the company (e.g. Perkins et al., 2016). However, what is often cited as a primary tool in eliciting economic behavior (Trisolini, 2011) that results in improved business performance (Galetić, 2015; Kato \& Kauhanen, 2018) is variable pay, incentive pay or pay for performance (PFP).

Even though the first PFP application can be traced to Frederick Taylor in the late 1800s and early 1900s (Thurkow, Bailey, \& Stamper, 2000), a revival in this practice occurred in the 1990s with PFP becoming the central concept of "The new pay" development (Trevor, 2013) when it was presumed that PFP systems would be dominantly used in order to retain and motivate employees. Besides a clear fit with motivation objectives, researchers have claimed that a high incentive-to-base pay ratio makes some labor costs variable and may help to attract and retain hard-working, risk-taking employees (Montemayor, 1996). In fact, it has been shown recently that the use of PFP is much more cost effective than a general pay rise (e.g. Burgess, Propper, Ratto, \& Tominey, 2017). Today, a more recent stream of economics and management literature has once again demonstrated a shift from the focus on pay level to an increased interest in PFP (see Gerhart, 2017).

Since PFP is typically introduced to answer a principal-agent problem (Lee-Meyer \& Doyle, 2017), PFP research focuses mainly on organizational performance (Park, Min, \& Chen, 2016). A large body of literature provides empirical evidence of a positive relation between PFP incentives and performance 
DRUŠ. ISTRAŽ. ZAGREB GOD. 29 (2020), BR. 1, STR. 71-90

KLINDŽIĆ, M., GALETIĆ, L.: COMBINING...
(Gallani, 2017) and/or productivity (e.g. Bucklin \& Dickinson, 2001; Kato \& Kauhanen, 2018). PFP research has also confirmed links to behavior-related outcomes such as creativity (e.g. Zhang, Long, Wu, \& Huang, 2015) and happiness (e.g. Park et al., 2016). Certain gaps, however, are still present in the literature regarding PFP. More precisely, research is usually strongly divided between examining either individual or collective PFP and their effects on various organizational outcomes. Studies that take into account the interplay between individual and collective PFP practices in the business environment and their joint effect on organizational performance are almost non-existent.

The recent and on-going interest in analyzing PFP in various contexts (e.g. Dahl \& Pierce, 2019; Gallani, 2017; Gerhart, 2017; Han \& Kim, 2018; Lee \& Meyer-Doyle, 2017; Nyberg, Maltarich, Abulsalam, Essman, \& Cragun, 2018) was an impetus to conduct a study which would bring a new perspective to the field. Consequently, in order to investigate the joint effect of bundles of PFP practices on organizational performance an empirical research study was undertaken on a sample of 61 middle- and large-sized companies in Croatia. The rest of the paper is organized as follows: firstly, available research on the individual and collective PFP as separate practices is presented. This is followed by an overview of available knowledge on bundles of PFP practices. Secondly, research methodology and research results are described in detail and, finally, after a discussion of research findings, comments on the main limitations, theoretical and practical contributions as well as prospects for future studies are given.

\section{THEORETICAL BACKGROUND ON PFP INCENTIVES AND THEIR RELATIONSHIP WITH ORGANIZATIONAL PERFORMANCE}

Compensation is generally considered to be of great strategic importance as it has implications for employee attraction, retention and performance (e.g. Galetić, 2015; Gross \& Friedman, 2004), which, in turn, have consequences for organizational performance (e.g. Chen \& Wang, 2018). PFP or variable pay is considered as "the practice of paying an amount of pay in addition to or instead of base pay as part of an employee's total remuneration which varies according to criteria" (CIPD, 2006 after Perkins et al., 2016). More generally, it is said that employers use variable forms of remuneration to elicit greater work efforts, to enhance employees' commitment, to attract better-quality workers or to act as a substitute for direct monitoring of worker performance by management (Pendleton, Whitfield, $\&$ Bryson, 2009). Both individual and group PFP practices have 
Generally speaking, two types of individual PFP incentives should be distinguished (Boeri, Lucifora, \& Murphy, 2013; Perkins et al., 2016): performance pay linked to any objective measure such as pieces produced per hour or value of contracts sold; and merit pay based on subjective measures generated either directly by a superior or more formally by a performance appraisal system. Central to individual PFP for all non-production-related jobs, as well as employees in science and R\&D (Galetić, 2015), is the concept of performance appraisal (PA), which is one of the core concepts of high performing work practices (HPWP) as well (Huselid, 1995). Employee PA scores are related to a range of important employment outcomes, including merit pay and bonuses, promotions, demotions and dismissals, as well as employee quits (Capelli \& Conyon, 2016). Several authors point out that different PAs have different foci, including those developmental, control, and results-oriented (e.g. Milkovich et al., 2016). However, Combs, Liu, Hall, and Ketchen (2006) argue that PAs need to be developmental in order to be effective. For some practices, such as incentive compensation, the specific version of the practice, such as group versus individual bonuses, might matter less than for other practices, such as developmental versus control-oriented PA (Combs et al., 2006).

It has been well established in the literature that individual-based bonus schemes, such as individual-based pay for performance, merit pay, sales commission incentives, and piece-rates, can have a positive effect on organizational performance (e.g., Kim, 2012). At the same time, evidence suggests that merit pay made on an individual basis is controversial; with some people believing it actually harms performance (Pfeffer, 1994). For example, it has been argued that monetary incentives, by focusing attention on the external reward related to a task, decrease intrinsic motivation and, thus, can decrease effort and task performance, as explained by cognitive evaluation theory (e.g., Deci \& Ryan, 1985). Burgess et al. (2017), for example, found little impact of the piece-rate scheme on quality measures, which they interpret as due to the differential measurement technology. In other contexts, it can also be explained by the fact that piece-rate compensation gives employees financial incentives to increase the quantity of services provided at the expense of quality when the deficiencies in quality are difficult to detect (Trisolini, 2011).

\section{Collective or group PFP practices}

Rewarding collective outcomes has become an increasingly important strategic motivational tool for driving collective success, reflecting the insight that paying employees for individual contributions does not always optimize performance in 
DRUŠ. ISTRAŽ. ZAGREB GOD. 29 (2020), BR. 1, STR. $71-90$

KLINDŽlÍ́, M., GALETIĆ, L.: COMBINING.. collective endeavors (Nyberg et al., 2018). The usual types of collective PFP practices discussed in the literature are (Galetić, 2015; Perkins et al., 2016): goal-sharing, gain-sharing, profit-sharing, employee-shared ownership (ESO) in the form of ESOP and stock options, and non-financial group recognition, with profit-sharing and ESO being dominantly explored.

Several potential beneficial effects of collective incentives have been identified in the literature, such as higher motivation and commitment, lower absenteeism and labor turnover and greater identification of workers with the interest of their firm (e.g., Kato \& Kauhanen, 2018; Perkins et al., 2016; Weitzman \& Kruse, 1990). However, different group incentives produce different outcomes. For example, it has been shown that long-term group incentives have a stronger relationship with psychological ownership while short-term group incentives have been found to be strongly related to organizational commitment (Han \& Kim, 2018).

As for specific types of group incentives, there is considerable evidence that e.g. profit-sharing has either a neutral or a positive effect on company economic performance (Fibírová \& Petera, 2013). In most cases, researchers have assessed corporate performance via income, investment and sales, and concluded that profit-sharing firms generally perform better and grow faster than non-profit-sharing firms (e.g., Florkowski, 1987; Pološki Vokić, Klindžić, \& Načinović Braje, 2016). This impact may be as a consequence of the direct influence of profit-sharing on employee productivity (due to the dependence of their pay on profit), but it seems that various mediating mechanisms may be more important, especially the effects on employment stability, absenteeism and related issues, as well as the effects on employee attitudes and on relationships between employees (see Fibírová \& Petera, 2013).

As regards employee-shared ownership, however, and its influence on organizational outcomes such as productivity or profitability, results are not as straightforward as in the case of profit-sharing schemes (Festing, Groening, Kabst, \& Weber, 1999). While there is sporadic evidence that ESO is associated with subsequent manager and employee performance (Capelli, Conyon, \& Almeda, 2019), as well as with organization performance through psychological ownership (Javed \& Idris, 2018), most studies have demonstrated that ESO improves employees' attitudes and behavior. More specifically, the rate of new product introduction is a function of stock options provided to employees in the most recent study of Agnihotri and Bhattacharya (2020, forthcoming), which implies that stock options can positively influence employee innovative work behaviour (e.g. Chen \& Weng, 2018; Usman, Xiao, \& Li, 2018). 


\section{Combining individual and group PFP practices - an overview of available arguments and studies}

An overview of studies available so far indicates that both individual and group incentives each have different beneficial effects on employees' and organizational performance. The former was confirmed by meta-analysis of 146 studies by Garbers and Konradt (2014) who examined the effects of both types of incentives on peoples' performance with the positive overall effect size of both types. Even though research comparing individual and group incentives as drivers of business performance is scarce (Brown, Lanis, \& Bairstow, 2010; Diez, 2017), studies combining both types of PFP are even harder to find. In an attempt to capture "the best of both worlds", researchers have often advocated compensation systems that contain elements of both types of incentives (e.g. Kozlowski \& Ilgen, 2006; Van Bavel \& Pecker, 2016) but have rarely attempted to undertake empirical research to confirm their assumptions.

Interestingly enough, there are several researchers who have contested the idea of mixing individual and group incentives even though they have not examined their claims empirically. For example, Barnes, Hollenbeck, Jundt, DeRue, and Harmon (2011) state that there are reasons to believe that mixed individual and collective PFP systems may act much less like group incentive systems than is generally believed. More specifically, they propose that combining individual and group incentives creates a conflict between the individual and collective interests of employees. Beersma et al. (2003) suggest that one potential form of defection in the context of team performance is avoiding information sharing and collective problem-solving behaviors that can prevent errors. Similarly, Barnes et al. (2008) do not provide empirical evidence but do suggest that mixed systems may promote effort but also defection.

There is considerable evidence, however, that focusing on only one type of PFP can result in adverse effects as well. Lee and Meyer-Doyle (2017) draw on the agency theory to explain how the firm's risk is transferred to the employee when an individual receives a compensation based on performance outcomes. A PFP scheme is a representative example of such risk transfer from the firm to the individual because a dominant portion of the individuals' overall compensation becomes dependent on their own performance (Lee \& Meyer-Doyle, 2017). On the other hand, when it comes to group PFP, the collective effort model (Karau \& Williams, 1993) shows that purely group-based incentives may lead to social loafing, i.e. the reduction of effort that occurs when individuals work collectively rather than independently (Barnes et al., 2011). 
DRUŠ. ISTRAŽ. ZAGREB GOD. 29 (2020), BR. 1, STR. 71-90

KLINDŽIĆ, M., GALETIĆ, L.: COMBINING..
Few empirical studies have been conducted on comparative effects of individual and collective PFP practices and especially with regard to their combination and the consequent effects on organizational outcomes. In the study of Thurkow et al. (2000) the relative effectiveness of three types of monetary incentive contingencies was estimated among the employees of a telephone research company based in Florida, USA. The results indicated that a combination of individual and group incentives produced a greater number of call completions per hour when compared to call completions observed under the baseline incentive contingencies, while the highest productivity rates were observed under individual incentive contingencies. More recently, Kato and Kauhanen (2018) exploited a panel nature of Finnish Linked Employer-Employee Data on the details of PFP and found that collective PFP are more powerful in boosting enterprise productivity than individual incentives.

When it comes to mixed individual and collective PFP practices, three studies offer insights into the area. In the experiment conducted among students at a large USA/Midwestern university, Barnes et al. (2011) have found that, in comparison to group only incentives, mixed individual/group incentives lead team members to perform faster but less accurately and focus on their own task work to the detriment of backing up behavior. A relatively recent research by Ladley, Wilkinson, and Young (2015) examines the effect of individual versus group incentives on work group behavior and performance under different task conditions by applying computational social methods to simulate work group interactions. They have found that group-based systems outperform individual-based and mixed systems, producing more cooperative behavior in most types of interaction games. Finally, the most recent study by De Speiegelare, Van Gyes, and Van Hootegem (2018) on PFP and innovative work behavior (IWB) conducted in Belgium on a sample of employees from several different industries has generated ambiguous results. More precisely, receiving both individual and collective PFP weakens the positive relation between learning opportunities and IWB and positively affects the relation between upward communication and IWB.

The disparate nature of findings of the few studies on combining individual and group incentives prompted us to examine the issue on a sample of organizations. The intention to examine a mixture of different PFP practices is backed up by MacDuffie (1995), according to whom the appropriate unit of analysis for studying the link between different human resource (HR) practices and competitiveness is an interrelated and internally consistent 'bundle' of practices, rather than individual practices. Such bundles create multiple reinforcing 
conditions that, according to Perry-Smith and Blum (2000), are consistent with ideas advanced in strategic HR research focusing on effective economic performance and recognizing $\mathrm{HR}$ as a primary source of sustainable competitive advantage.

\section{EMPIRICAL RESEARCH ON BUNDLES OF PFP INCENTIVES AND THEIR RELATIONSHIP WITH ORGANIZATIONAL PERFORMANCE}

\section{Research methods}

Research instrument. Our empirical research instrument was designed as a questionnaire comprising a total of 46 questions. It was used to collect data on compensation management systems in general. The majority of key questions about different reward management practices were either constructed by authors or adapted from different journal articles and internal materials of the Chartered Institute for Personnel Development. The average time taken to fulfill the questionnaire was between 30 and 45 minutes.

Measures. As for the independent variables, two groups of PFP practices were used. Individual PFP practices that were analyzed in the study are those most commonly referred to in the literature i.e. performance appraisal, superior's subjective assessment-based occasional bonuses, sales commissions and non-financial individual recognition. As for the group PFP practices, several were analyzed in the study: goal-sharing, profit-sharing, ESOP, stock options and non-financial group recognition. In both cases, the respondents could also opt for "none of the previously mentioned practices". In total, 9 different variable PFP practices were analyzed. All PFP variables were treated as dichotomous variables, i.e. respondents were asked to provide information on whether a certain PFP practice existed $($ yes $=1)$ or not $($ no $=0)$ in their organization for the key personnel i.e. managers and talented employees. The dependent variables in this study were: productivity and profitability, which are among the most commonly used measures of performance (Huselid, 1995), as well as two non-financial measures of performance, i.e. quality of services or products and innovativeness, all treated as continuous variables. The respondents were asked to assess these four measures on a Likert type 5-point scale where 1 represented the lowest level while 5 represented the highest level of the state of the observed measures of organization performance. Finally, independent characteristics of the companies that were taken into account were: their size measured by number of employees, year of establishment and industry, ownership structure (private domestic, private foreign, state-owned, mixed) and legal form (limited liability company or joint stock company). 
DRUŠ. ISTRAŽ. ZAGREB GOD. 29 (2020), BR. 1, STR. 71-90

KLINDŽIĆ, M., GALETIĆ, L.: COMBINING..

(1) TABLE 1

Sample characteristics by industry, year of establishment, number of employees, ownership structure and legal form
Sample. The selection of study participants was conducted bearing in mind that the large and medium-sized companies are expected to have more sophisticated HRM practices in general (Kotey \& Sheridan, 2004) and reward practices specifically. According to the relevant national Accountancy Act (National Gazette, 2010), enterprises are considered medium-sized if they employ between 100 and 250 employees, and large if they employ more than 250 employees. The population of Croatian companies (excluding the banking and finance sector) with more than 100 employees was obtained through the Croatian Chamber of Commerce (CCC) database. It was revealed that approximately 1700 companies employ more than 100 people, out of which 386 companies employ more than 250 people.

Data collection process and analysis. After the population of middle and large-sized companies was identified, an online questionnaire accompanied by a cover letter from the project leader was sent to HR department managers of all companies in the CCC database in April 2017. Reminders were sent out in May and June, followed by personal reminders using project members' professional networks. Upon the receipt of the 61st questionnaire in October 2017, the data collection phase was concluded and a statistical analysis of the primary data with IBM SPSS 20.0 performed. The independent characteristics of the companies in the sample are given in Table 1 . The following methods and tests were used in this research study: descriptive statistics, correlation analysis, categorical principal component analysis and multiple regression analysis.
Company characteristic

Industry

Year of establishment

Number of employees

Ownership structure

Legal form
Data distribution
Manufacturing $-55.70 \%$, services $-44.30 \%$

Before 1990 - $43.30 \%$, after $1990-56.70 \%$

Less than $250-52.50 \%$, more than $250-47.50 \%$

Private domestic $-55.70 \%$, private foreign $-32.80 \%$, state-owned and mixed $-11.50 \%$

Joint stock company $-32.80 \%$, limited liability company $-67.20 \%$

Both manufacturing and service companies are almost equally represented in the sample, as are the companies that employ less than 250 and more than 250 people (middle-sized and large-sized companies, respectively). As for the establishment age, companies founded after 1990, when central planning was abandoned, slightly prevailed (56\%). When it comes to ownership structure, more than half of the sample is comprised of private domestic companies, one-third of the sample are privately-owned foreign companies, while state-owned 
and companies with mixed ownership are underrepresented (10.80\% combined). Limited liability companies form a majority $(66 \%)$, while the rest are joint stock companies (34\%).

\section{Research results}

(1) TABLE 2

The distribution of different PFP practices in the sample
As mentioned earlier, the presence of 9 different individual and group PFP practices was examined by the questionnaire (results are shown in Table 2). Upon analyzing the data, it was revealed that performance appraisal was found in more than half of the examined companies, while occasional bonuses based on subjective evaluation as well as individual non-financial recognition were applied in $41 \%$ of the sampled companies. Additionally, sales commissions as the only objectively-based measure of individual performance, were found in approximately $30 \%$ of the companies. Group incentives, however, were less prevalent. Group non-financial recognition was found in $26 \%$ of companies, followed by profit-sharing and goal-sharing, which occur in approximately $20 \%$ of the cases. Employee-shared ownership in the form of ESOP and stock options was found in approximately $12 \%$ of the companies taking part in this study. Interestingly, while only $5 \%$ of the companies reported that none of the individual PFP was used, almost $38 \%$ of companies had no group incentives applied for their managerial staff and talented employees.

\begin{tabular}{lrlr} 
Type of individual PFP incentive & $\%$ of sample & Type of group PFP incentive & $\%$ of sample \\
\hline Sales commissions & 29.51 & Goal-sharing & 19.67 \\
Superior subjectively-assessed & & Profit-sharing & 19.67 \\
$\quad$ occasional bonuses & 40.98 & Employee Shared Ownership Program & 11.47 \\
Performance appraisal & 50.82 & Share options & 11.47 \\
Individual non-financial recognition & 40.98 & Group non-financial recognition & 26.23 \\
None of the above & 4.92 & None of the above & 37.70
\end{tabular}

The next step included identifying combinations of PFP practices that could be used as factors in the following step of the analysis. A confirmatory factor analysis (CFA) with ordinary maximum likelihood (ML) would be the method of choice. However, since our variables are of categorical (i.e. dichotomous) nature, a different strategy was sought. As explained by Brown (2006), the potential negative consequences of treating categorical variables as continuous variables in CFA are multifold, including attenuated estimates of the correlations among indicators and incorrect parameter estimates, test statistics and standard errors. Instead, a Principal Component Analysis (PCA) with nonlinear optimal scaling transformations for ordinal and categorical data (NLPCA) was found to be a more adequate technique. NLPCA does not make assump- 
DRUŠ. ISTRAŽ. ZAGREB GOD. 29 (2020), BR. 1, STR. 71-90

KLINDŽIĆ, M., GALETIĆ, L.: COMBINING..

(1) TABLE 3

The component loadings of individual and group PFP factors tions concerning the measurement level of the variables and the nature of their relationships, but analyzes the data at a level specified by the researcher (interval, ordinal, or nominal), resulting in quantifications of the categorical variables that reveal the shape of the relations between them (Manisera, van der Kooij, \& Dusseldorp, 2010).

For the purpose of data analysis, the CatPCA feature of IBM SPSS 20.00 was used which allows for the measurement of nonlinear relationships between variables (Mendes \& Ganga, 2013). In this specific case, the weight for variables must be a positive integer and was set to a default value of 1 . The normalization method chosen for the analysis was Variable Principle, which optimizes the association between variables. The coordinates of the variables in the object space are the component loadings (correlations with principal components, such as dimensions and object scores). The CatPCA procedure generated a two-factor solution with Cronbach Alpha for both factors deemed satisfactory $(\alpha=0.809)$. Due to sample size, loadings cut-off was set to 0.5. Factors are shown in Table 3.

Groups of PFP practices

Dimension / Component Loadings

\begin{tabular}{llrr}
\hline Individual PFP & Performance appraisal & 0.304 & 0.741 \\
& Sales commissions & -0.585 & 0.020 \\
Subjectively-assessed individual bonus & 0.540 & 0.402 \\
Non-financial individual recognition & 0.087 & 0.415 \\
Group PFP & Goal-sharing & 0.148 & 0.079 \\
& Profit-sharing & -0.062 & 0.708 \\
& ESOP & 0.619 & -0.473 \\
& Stock options & 0.830 & -0.116 \\
Non-financial group recognition & 0.272 & -0.166 \\
Method & Variable Principal Normalization & &
\end{tabular}

According to research results, PFP practices that loaded on the first factor were the subjectively-assessed individual bonus and two group PFP practices related to employee-shared ownership (ESOP and stock options). Practices that loaded on the second factor were again a combination of individual and group practices, i.e. performance appraisal and profit-sharing. Once the factors were identified, the final step was to enter them into multiple regression analysis in order to test their influence on selected indicators of organizational performance. The descriptive statistics of the dependent variables is shown in Table 4.

Both financial and non-financial indicators of organizational performance are assessed as being either average or slightly better than those of competitors $(M>3,5)$. Non-financial in- 
() TABLE 4

The distribution of and correlations between different organizational performance outcomes dicators show both higher average values compared to the first group of indicators as well as higher though moderate correlation $(\mathrm{r}=0.554, p=0.01)$. Factors 1 and 2 were regressed on all four indicators of organizational performance and details are summarized in Table 5.

\begin{tabular}{lllllll}
\hline Indicators & $\mathrm{M}$ & $\sigma$ & 1 & 2 & 3 & 4 \\
\hline 1 Productivity & 3.53 & 0.83 & 1 & & & \\
2 Profitability & 3.42 & 0.85 & $0.358^{* *}$ & 1 & & \\
3 Quality of products or services & 4.07 & 0.69 & 0.169 & $0.422^{* *}$ & 1 & \\
4 Innovativeness & 3.88 & 0.70 & -0.026 & -0.026 & $0.554^{* *}$ & 1
\end{tabular}

${ }^{* *}$ Correlation is significant at the 0.01 level (2-tailed).

\begin{tabular}{rrrrr}
\hline & Unstandardized & Standardized \\
coefficients & coefficients & & \\
Model & B Std. Error & Beta & t & Sig. \\
\hline
\end{tabular}

Productivity $\mathrm{R}=0.354, \mathrm{R}$ squared $=0.125$, Sig. $=0.027$

\begin{tabular}{|c|c|c|c|c|}
\hline Constant & 3.545 & 0.104 & & 33.942 \\
\hline Factor 1 & 0.092 & 0.104 & 0.112 & 0.877 \\
\hline Factor 2 & 0.274 & 0.104 & 0.336 & 2.636 \\
\hline
\end{tabular}

Profitability $R=0.334, \mathrm{R}$ squared $=0.112$, Sig. $=0.055$

$\begin{array}{lrrrrr}\text { Constant } & 3.423 & 0.114 & & 30.044 & 0.000 \\ \text { Factor 1 } & -0.028 & 0.127 & -0.029 & -0.218 & 0.828 \\ \text { Factor 2 } & 0.269 & 0.108 & 0.335 & 2.481 & 0.017\end{array}$

Quality of products and services $\mathrm{R}=0.083$, $\mathrm{R}$ squared $=0.05$, Sig. $=0.088$

\begin{tabular}{|c|c|c|c|c|}
\hline Constant & 4.075 & 0.088 & & 46.409 \\
\hline Factor 1 & 0.200 & 0.089 & 0.288 & 2.250 \\
\hline Factor 2 & 0.016 & 0.088 & 0.023 & 0.179 \\
\hline
\end{tabular}

Innovativeness $\mathrm{R}=0.145$, $\mathrm{R}$ squared $=0.114$, Sig. $=0.013$

$\begin{array}{llllrl}4 \text { Constant } & 3.892 & 0.085 & & 45.527 & 0.000 \\ \text { Factor 1 } & 0.263 & 0.087 & 0.375 & 3.037 & 0.004 \\ \text { Factor 2 } & 0.048 & 0.086 & 0.069 & 0.558 & 0.579\end{array}$

(1) TABLE 5

The summary of multiple regression analyses
Of four models presented in Table 5, two were statistically significant at 0.05 level (Productivity, $\mathrm{R}=0.354, p<0.027$; Innovativeness, $\mathrm{R}=0.145, p<0.013$ ) while the other two were significant at 0.10 level (Profitability, $\mathrm{R}=0.334, p<0.055$; Quality of products and services, $\mathrm{R}=0.083, p<0.088)$. The percentage of variance accounted for was the highest in case of productivity $(12.5 \%)$, followed by innovativeness $(11.4 \%)$ and profitability $(11.2 \%)$, and very low for quality of products and services (5\%). Research findings suggest that the first factor, i.e. a combination of occasional individual bonuses and shared ownership results in enhanced organizational perfor- 
DRUŠ. ISTRAŽ. ZAGREB GOD. 29 (2020), BR. 1, STR. 71-90

KLINDŽIĆ, M., GALETIĆ, L.:

COMBINING.. mance as measured by non-financial indicators. More precisely, it was found that the presence of the aforementioned combination of individual bonus and ESO positively influences product/service quality $(p=0.028)$ and innovativeness $(p=0.004)$. On the other hand, the second factor, i.e. the combination of performance appraisal and profit-sharing, was found to positively influence financial indicators of company performance, i.e. productivity $(p=0.010)$ and profitability $(p=0.017)$.

\section{DISCUSSION AND CONCLUSION}

Several important findings were generated by the empirical research conducted on the sample of middle and large-sized companies in Croatia. First of all, two bundles of practices related to PFP practices were identified. More precisely, the first bundle consisted of individual subjectively-assessed bonus and two shared-ownership practices while the second bundle included individual performance-appraisal and group practice of profit-sharing. Similar to the second factor, Addison and Belfield (2008) found that training and profit-related pay tend to be adopted together with performance appraisal. These findings are in line with a stream of research related to HPWP (e.g. Perry-Smith \& Bloom, 2000) which promotes the application of several types of reward incentives instead of focusing on just one reward practice. Moreover, the widespread enthusiasm for PFP over the recent years reflects the theory that quality and efficiency can be improved by focusing on economic incentives (Trisolini, 2011), which the second research finding indeed suggests.

More specifically, bundles of PFP practices were regressed on four different organizational performance indicators and the analysis generated several important findings. With regard to the financial indicators of organizational performance, i.e. productivity and profitability, the second bundle of PFP practices that combines performance appraisal and profit-sharing was found to be of positive, significant influence, especially with regard to productivity. Profit-sharing is generally considered to have a positive effect on company productivity (e.g. Festing et al., 1999); however, it has been demonstrated that companies with only one group incentive (e.g. only profit-sharing) do not necessarily achieve better performance than average companies (e.g. Addison \& Belfield, 2000). The performance appraisal process and other HR-related practices (e.g. feedback information, career advancement, education and development) that result from this process could be the factor that contribute to or strengthen the influence of profit-sharing on individual and company productivity. These results may imply that employers acknowledge the existence 
DRUŠ. ISTRAŽ. ZAGREB GOD. 29 (2020), BR. 1, STR. 71-90

KLINDŽIĆ, M., GALETIĆ, L.: COMBINING.. of complementarities or synergies between HRM practices and, consequently, adopt performance appraisal jointly with other practices, as postulated by Bayo-Moriones, Galdon-Sanchez and Martinez-de-Morentin (2019). This especially holds true from the viewpoint of implicit rewards that could be expected from the performance appraisal process. Indeed, Gallani (2017) finds that monetary incentives are associated with a higher likelihood and greater magnitude of performance improvements during the incentive period, but are relatively short-lived, while implicit incentives facilitate a longer persistence of organizational behavior modification. Additionally, the review published by Bucklin and Dickinson (2001) revealed that a combination of monetary incentives with feedback led to an improvement of performance when compared to hourly pay plus feedback in studies in all thematic research lines.

With regard to non-financial indicators of organizational performance, this research suggests that a combination of individual subjectively-based bonus and group shared-ownership results in a significant (though small) influence on quality of products and services. The combination, however, especially enhances company innovativeness. This is in line with Baumann and Stieglitz's (2014 after Lee \& Meyer-Doyle, 2017) simulation model which suggests that using low-powered performance-based incentives can be a more effective tool to motivate employees to continuously come up with new ideas and produce innovation. On the other hand, Lee and Meyer-Doyle (2017) find that individuals engage in more exploration, i.e. innovative behavior, after a reduction in performance-based incentives. Interestingly, however, the increase in exploration is largely driven by high-performing individuals. Since most studies find evidence that ESO improves employees' attitudes and behavior, i.e. aligns individual and company goals, strengthens psychological ownership (Han \& Kim, 2018; Javed \& Idris, 2018), contributes to higher work engagement (Galetić, 2015), is a function of new product launch (e.g. Agnihotri \& Bhattacharya, 2020), and results in more innovation (Chen \& Wang, 2018), the positive influence of the second bundle could stem from the balance that is created by the amalgamation of short-term individual and long-term group reward practices.

Practical implications of this study are twofold. Firstly, while attempting to design a reward system that would elicit desirable employee behaviors and, consequently, enhance organizational performance, managers should strive to include both types of PFP practices into the reward system. In other words, both individual incentives that stimulate employees who are motivated by achievement and group incentives that connect 
DRUŠ. ISTRAŽ. ZAGREB GOD. 29 (2020), BR. 1, STR. 71-90

KLINDŽIĆ, M., GALETIĆ, L.: COMBINING..

\section{REFERENCES}

personal and organizational interests should constitute the part of pay that is considered as "variable". Secondly, it could be deduced that certain combinations of PFP practices stimulate specific organization outcomes. Precisely, a combination of shared ownership and individual subjectively-assessed bonus contributes to company innovativeness, which is nowadays addressed as one of the primary sources of competitive advantage. On the other hand, a combination of profit-sharing and individual performance appraisal (and its direct/indirect outcomes) could contribute to organizational productivity.

The main limitation of this research is the fact that the empirical data is of cross-sectional nature. Future research should therefore aim at gathering longitudinal data in order to establish causal relations among different variables. Additionally, since the sample consists of only 61 companies, researchers could try to cover a higher percentage of population in order to be able to generalize research findings. Also, the questionnaire was filled out by one person only, i.e. the HR manager. Even though the respondents were guaranteed anonymity to increase the accuracy of the responses and the expertise of the respondents could be deemed unquestionable, the problem of response bias still remains in social research in general. In future studies, the questionnaire could be distributed personally and be accompanied by an interview. Additionally, even though only four mainstream indicators of organizational performance were used in the study, there is no consensus among researchers and practitioners regarding the choice of indicators and criteria to be applied in selecting them (Bakotić, 2014). However, additional, independent data, i.e. financial indicators from public reports, could be paired with the data gathered by cross-sectional research, adding strength to the findings and avoiding response bias. Finally, the comparatively low explained variance relative to total variance in the dependent variable is an additional limitation of the study; however, Falk and Miller (1992) recommended that R squared values should be equal to or greater than 0.10 in order for the variance explained of a particular endogenous construct to be deemed adequate, which holds true in three out of four models in the present research.

Addison, J. T., \& Belfield, C. R. (2000). The impact of financial participation and employee involvement on financial performance: A reestimation using the 1998 Wers. Scottish Journal of Political Economy, 47(5), 571-583. https://doi.org/10.1111/1467-9485.00179

Addison, J. T., \& Belfield, C. R. (2008). The determinants of performance appraisal systems: A note (Do Brown and Heywood's results for Australia hold up for Britain?). British Journal of Industrial Relations, 46(3), 521-531. https://doi.org/10.1111/j.1467-8543.2008.00691.x 
DRUŠ. ISTRAŽ. ZAGREB GOD. 29 (2020), BR. 1, STR. 71-90

KLINDŽIĆ, M., GALETIĆ, L.: COMBINING...
Agnihotri, A., \& Bhattacharya, S. (2020, forthcoming). ESOPs and new product launch: Conditional effects of financial slack and ownership concentration. International Journal of Innovation Management. https://doi.org/10.1142/S1363919620500218

Bakotić, D. (2014). Suvremeni modeli za mjerenje organizacijskih performansi [Contemporary performance measurement systems]. Ekonomska misao i praksa, 22(1), 373-388.

Barnes, C. M., Hollenbeck, J. R., Jundt, D. K., DeRue, D. S., \& Harmon, S. J. (2011). Mixing individual incentives and group incentives: Best of both worlds or social dilemma? Journal of Management, 37(6), 1611-1635. https://doi.org/10.1177/0149206309360845

Barnes, C. M., Hollenbeck, J. R., Wagner, D. T., DeRue, D. S., Nahrgang, J. D., \& Schwind, K. M. (2008). Harmful help: The costs of backing-up behavior in teams. Journal of Applied Psychology, 93(3), 529-539. https://doi.org/10.1037/0021-9010.93.3.529

Bayo-Moriones, A., Galdon-Sanchez, J. E., \& Martinez-de-Morentin, S. (2019). Performance appraisal: Dimensions and determinants. The International Journal of Human Resource Management (in press). https://doi. org/10.1080/09585192.2018.1500387

Beersma, B., Hollenbeck, J. R., Humphrey, S. E., Moon, H., Conlon, D. E., \& Ilgen, D. R. (2003). Cooperation, competition, and team performance: Toward a contingency approach. Academy of Management Journal, 46(5), 572-590. https://doi.org/10.5465/30040650

Boeri, T., Lucifora, C., \& Murphy, K. (2013). Executive remuneration and employee performance-related pay: A transatlantic perspective. Oxford: Oxford University Press. https://doi.org/10.1093/acprof:oso/9780199 669806.001 .0001

Brown, P., Lanis, R., \& Bairstow, G. (2010). The impact of group versus individual incentives on innovation and organizational performance. Sydney: University of Technology.

Brown, T. (2006). Confirmatory factor analysis for applied research. New York: The Guilford Press.

Bucklin, B., \& Dickinson, A. (2001). Individual monetary incentives. Journal of Organizational Behavior Management, 21(3), 45-137. https://doi. org/10.1300/J075v21n03_03

Burgess, S. M., Propper, C., Ratto, M., \& Tominey, E. (2017). Incentives in the public sector: Evidence from a government agency. The Economic Journal, 127(605), 117-141. https://doi.org/10.1111/ecoj.12422

Capelli, P., \& Conyon, M. (2016). What do performance appraisals do? NBER working paper series, Working Paper 22400, National bureau of economic research, Cambridge. https://doi.org/10.3386/w22400

Capelli, P., Conyon, M., \& Almeda, D. (2019). Social exchange and the effects of employee stock options. ILR Review (in press). https://doi. org/10.1177/0019793919827934

Chen, L., \& Wang, J. (2018). Business strategy, compensation policy and innovation performance: A behavioral perspective. Compensation $\mathcal{E}$ Benefits Review, 49(4), 189-205. https://doi.org/10.1177/08863687187 98423 
DRUŠ. ISTRAŽ. ZAGREB GOD. 29 (2020), BR. 1, STR. 71-90

KLINDŽİ́, M., GALETIĆ, L.: COMBINING..
Combs, J., Liu, Y., Hall, A., \& Ketchen, D. (2006). How much do high-performance work practices matter? A meta-analysis of their effects on organizational performance. Personnel Psychology, 59(3), 501-528. https://doi.org/10.1111/j.1744-6570.2006.00045.x

Dahl, M., \& Pierce, L. (2019). Pay-for-performance and employee mental health: Large sample evidence using employee prescription drug usage. Academy of Management Discoveries (in press). https://doi. org/10.5465/amd.2018.0007

Deci, E. L., \& Ryan, R. M. (1985). Intrinsic motivation and self-determination in human behavior. New York: Plenum. https://doi.org/10.1007/ 978-1-4899-2271-7

De Spiegelaere, S., Van Gyes, G., \& Van Hootegem, G. (2018). Innovative work behaviour and performance related pay: Rewarding the individual or the collective? The International Journal of Human Resource Management, 29(12), 1900-1919. https://doi.org/10.1080/095851 92.2016.1216873

Diez, F. D. (2017). Pay for performance: What type of pay scheme is best for achieving business results? (PhD Dissertation). Singapore Management University, Singapore.

Falk, R. F., \& Miller, N. B. (1992). A primer for soft modeling. Akron: The University of Akron.

Festing, M., Groening, Y., Kabst, R., \& Weber, W. (1999). Financial participation in Europe - Determinants and outcomes. Economic and Industrial Democracy, 20(2), 295-329. https://doi.org/10.1177/0143831X 99202007

Fibírová, J., \& Petera, P. (2013). Profit-sharing - A tool for improving productivity, profitability and competitiveness of firms? Journal of Competitiveness, 5(4), 3-25. https://doi.org/10.7441/joc.2013.04.01

Florkowski, G. W. (1987). The organizational impact of profit sharing. The Academy of Management Review, 12(4), 622-636. https://doi.org/10. $2307 / 258068$

Galetić, L. (2015). Kompenzacijski menadžment [Compensation management]. Zagreb: Sinergija.

Gallani, S. (2017). Incentives, peer pressure, and behavior persistence. Working Paper 17-070. Boston: Harvard Business School. https://doi.org/ $10.2139 /$ ssrn.2897572

Garbers, Y., \& Konradt, U. (2014). The effect of financial incentives on performance: A quantitative review of individual and team-based financial incentives. Occupational and Organizational Psychology, 87(1), 102-137. https://doi.org/10.1111/joop.12039

Gerhart, B. (2017). Incentives and pay for performance in the workplace. In A. J. Elliot (Ed.), Advances in motivation science (Vol. 4, pp. 91-140). Elsevier Academic Press. https://doi.org/10.1016/bs.adms.2017.02.001

Gross, S. E., \& Friedman, H. M. (2004). Creating an effective total rewards strategy: Holistic approach better supports business success. Benefits Quarterly, 20(3), 7-12.

Han, K., \& Kim, A. (2018). Differential impact of short-term and long-term group incentives. Employee Relations, 40(3), 549-564. https://doi. org/10.1108/ER-10-2016-0202 
DRUŠ. ISTRAŽ. ZAGREB GOD. 29 (2020), BR. 1, STR. 71-90

KLINDŽIĆ, M., GALETIĆ, L.: COMBINING...
Huselid, M. A. (1995). The impact of human resource management practices on turnover, productivity, and corporate financial performance. Academy of Management Journal, 38(3), 635-672. https://doi.org/ $10.5465 / 256741$

Javed, T., \& Idris, S. (2018). Impact of employee ownership on an organizational productivity: A mediating role of psychological ownership. Academy of Accounting and Financial Studies Journal, 22(2), 1-12. Karau, S. J., \& Williams, K. D. (1993). Social loafing: A meta-analytic review and theoretical integration. Journal of Personality and Social Psychology, 65(4), 681-706. https://doi.org/10.1037/0022-3514.65.4.681

Kato, T., \& Kauhanen, A. (2018). Performance pay and enterprise productivity: The details matter. IZA Discussion Papers, No. 11523, Institute of Labor Economics (IZA), Bonn.

Kim, W. (2012). A study on compensation strategies and their effects on corporations in a global context. (Master thesis). The Pennsylvania State University, Penn State.

Kotey, B., \& Sheridan, A. (2004). Changing HRM practices with firm growth. Journal of Small Business and Enterprise Development, 11(4), 474-486. https://doi.org/10.1108/14626000410567125

Kozlowski, S. W. J., \& Ilgen, D. R. (2006). Enhancing the effectiveness of work groups and teams. Psychological Science in the Public Interest, 7(3), 77-124. https://doi.org/10.1111/j.1529-1006.2006.00030.x

Ladley, D., Wilkinson, I., \& Young, L. (2015). The impact of individual versus group rewards on work group performance and cooperation: A computational social science approach. Journal of Business Research, 68(11), 2412-2425. https://doi.org/10.1016/j.jbusres.2015.02.020

Lee, S., \& Meyer-Doyle, P. (2017). How performance incentives shape individual exploration and exploitation: Evidence from microdata. Organization Science, 28(1), 19-38. https://doi.org/10.1287/orsc. 2016.1104

MacDuffie, J. P. (1995). Human resource bundles and manufacturing performance: Organizational logic and flexible production systems in the world auto industry. Industrial and Labor Relations Review, 48(2), 197-221. https://doi.org/10.2307/2524483

Manisera, M., van der Kooij, A. J., \& Dusseldorp, E. (2010). Identifying the component structure of satisfaction scales by nonlinear principal components analysis. Quality Technology \& Quantitative Management, 7(2), 97-115. https://doi.org/10.1080/16843703.2010.11673222

Mendes, G. H., \& Ganga, G. M. D. (2013). Predicting success in product development: The application of principal component analysis to categorical data and binomial logistic regression. Journal of Technology Management $\mathcal{E}$ Innovation, 8(3), 83-97. https://doi.org/10.4067/S0 718-27242013000400008

Milkovich, G., Newman, J., \& Gerhart, B. (2016). Compensation. New York: McGraw Hill.

Montemayor, E. (1996). Congruence between pay policy and competitive strategy in high-performing firms. Journal of Management, 22(6), 889-908. https://doi.org/10.1177/014920639602200605

National Gazette (2010). Accountancy act, 120/16. Zagreb: National Gazette plc. 
DRUŠ. ISTRAŽ. ZAGREB GOD. 29 (2020), BR. 1, STR. 71-90

KLINDŽİ́, M., GALETIĆ, L.: COMBINING..
Nyberg, A. J., Maltarich, M. A., Abdulsalam, D. D., Essman, S. M., \& Cragun, O. (2018). Collective pay for performance: A cross-disciplinary review and meta-analysis. Journal of Management, 44(6), 24332472. https://doi.org/10.1177/0149206318770732

Park, S., Min, K., \& Chen, C. (2016). Do monetary rewards bring happiness? Comparing the impacts of pay-for-performance in the public and private sectors. International Review of Public Administration, 21(3), 199-215. https://doi.org/10.1080/12294659.2016.1237092

Pendleton, A., Whitfield, K., \& Bryson, A. (2009). The changing use of contingent pay at the modern British workplace. In W. Brown, A. Bryson, J. Forth, \& K. Whitfield (Eds.), The evolution of the modern workplace (pp. 256-284). Cambridge: Cambridge University Press.

Perkins, S., White, G., \& Jones, S. (2016). Reward management: Alternatives, consequences and contexts. London: CIPD.

Perry-Smith, J. E., \& Blum, T. C. (2000). Work-family human resource bundles and perceived organizational performance. The Academy of Management Journal, 43(6), 1107-1117. https://doi.org/10.5465/1556339

Pfeffer, J. (1994). Competitive advantage through people: Unleashing the power of the workforce. Boston: Harvard Business School Press.

Pološki Vokić, N., Klindžić, M., \& Načinović Braje, I. (2016). Determinants of financial participation - two decades of Croatian practice. In S. Fietze, \& W. Matiaske (Eds.), Dimensions and perspectives on financial participation in Europe (pp. 425-458). Baden Baden: Nomos Publishing. https://doi.org/10.5771/9783845259413-424

Thurkow, N. M., Bailey, J. S., \& Stamper, M. R. (2000). The effects of group and individual monetary incentives on productivity of telephone interviewers. Journal of Organizational Behavior Management, 20(2), 3-26. https://doi.org/10.1300/J075v20n02_02

Trevor, J. (2013). From new pay to the new, new pay? WorldAtWork Journal, First Quarter, 19-28.

Trisolini, M. (2011). Theoretical perspectives on pay for performance. In J. Cromwell, M. G. Trisolini, G. C. Pope, J. B. Mitchell, \& L. M. Greenwald (Eds.), Pay for performance in health care: Methods and approaches (pp. 77-98). Research Triangle Park, NC: RTI Press. https://doi.org/10. 3768/rtipress.2011.bk.0002.1103.3

Usman, M., Xiao, S., \& Li, W. (2018). Employee stock-option and share-ownership effects on innovation. Human Systems Management, 37(2), 161-168. https://doi.org/10.3233/HSM-17231

Van Bavel, J., \& Pecker, D. (2016). The problem with rewarding individual performers. Harvard Business Review. Available at https://hbr.org/ 2016/12/the-problem-with-rewarding-individual-performers [accessed October 01, 2018]

Weitzman, M. L., \& Kruse, D. L. (1990). Profit sharing and productivity. In A. S. Blinder (Ed.), Paying for productivity: A look at the evidence (pp. 95-140). Washington: Brookings.

Zhang, Y., Long, L., Wu, T., \& Huang, X. (2015). When is pay for performance related to employee creativity in the Chinese context? The role of guanxi HRM practice, trust in management, and intrinsic motivation. Journal of Organizational Behavior. Special Issue: Organizational Behavior in China, 36(5), 698-719. https://doi.org/10.1002/job.2012 
DRUŠ. ISTRAŽ. ZAGREB GOD. 29 (2020), BR. 1, STR. 71-90

KLINDŽIĆ, M., GALETIĆ, L.: COMBINING..

\section{Unaprjeđenje organizacijske uspješnosti kroz individualne i kolektivne prakse varijabilnoga nagrađivanja zaposlenika}

Maja KLINDŽıĆ, Lovorka GALETIĆ

Ekonomski fakultet, Zagreb

Mnoge studije upozoravaju na pozitivnu vezu između praksi nagrađivanja zaposlenika i uspješnosti pojedinca ili organizacija; međutim, samo nekoliko studija dostupno je na temu kombiniranja, odnosno istodobne primjene individualnoga $i$ grupnoga varijabilnog nagrađivanja da bi se unaprijedila organizacijska uspješnost. U ovom radu istražuju se upravo skupovi, odnosno kombinacije, 9 praksi individualnog i grupnog nagrađivanja, odnosno njihov utjecaj na odabrane indikatore organizacijske uspješnosti. Empirijsko istraživanje provedeno je na uzorku od 61 srednje velikoga i velikoga poduzeća u Hrvatskoj da bi se analizirale prethodno spomenute veze. Analiza glavnih komponenata za kategoričke varijable generirala je dva faktora varijabilnih praksi nagrađivanja koje su uvedene kao nezavisne varijable u 4 modela višestruke regresije. Prvi faktor varijabilnih praksi nagrađivanja sastoji se od individualnih bonusa na temelju procjene nadređenoga menadžera i dvije grupne prakse temeliene na participaciji zaposlenika u vlasništvu poduzeća. Spomenuti faktor pozitivno utječe na nefinancijske indikatore poduzeća, odnosno kvalitetu proizvoda i usluga i inovativnost. Drugi faktor, koji se sastojao od individualnog ocjenjivanja radne uspješnosti i sudjelovanja u profitu poduzeća, pozitivno utječe na financijske pokazatelje uspješnosti, odnosno na produktivnost, te, u manjoj mieri, na profitabilnost poduzeća. Opisane su implikacije za teoriju i praksu.

Ključne riječi: upravljanje nagrađivanjem, plaća na temelju učinka, individualni bonus, grupni bonus, skupovi praksi nagrađivanja

\section{(c) (i) (5)}

Međunarodna licenca / International License:

Imenovanje-Nekomercijalno / Attribution-NonCommercial 